\title{
Viral Gastroenteritis
}

National Cancer Institute

\section{Source}

National Cancer Institute. Viral Gastroenteritis. NCI Thesaurus. Code C35374.

Gastroenteritis resulting from a viral infection. 